Prepared for the U.S. Department of Energy under Contract DE-AC05-76RL01830

\title{
Pacific Northwest National Laboratory Potential Impact Categories for Radiological Air Emission Monitoring
}

\author{
MY Ballinger \\ TL Gervais \\ JM Barnett
}

June 2012

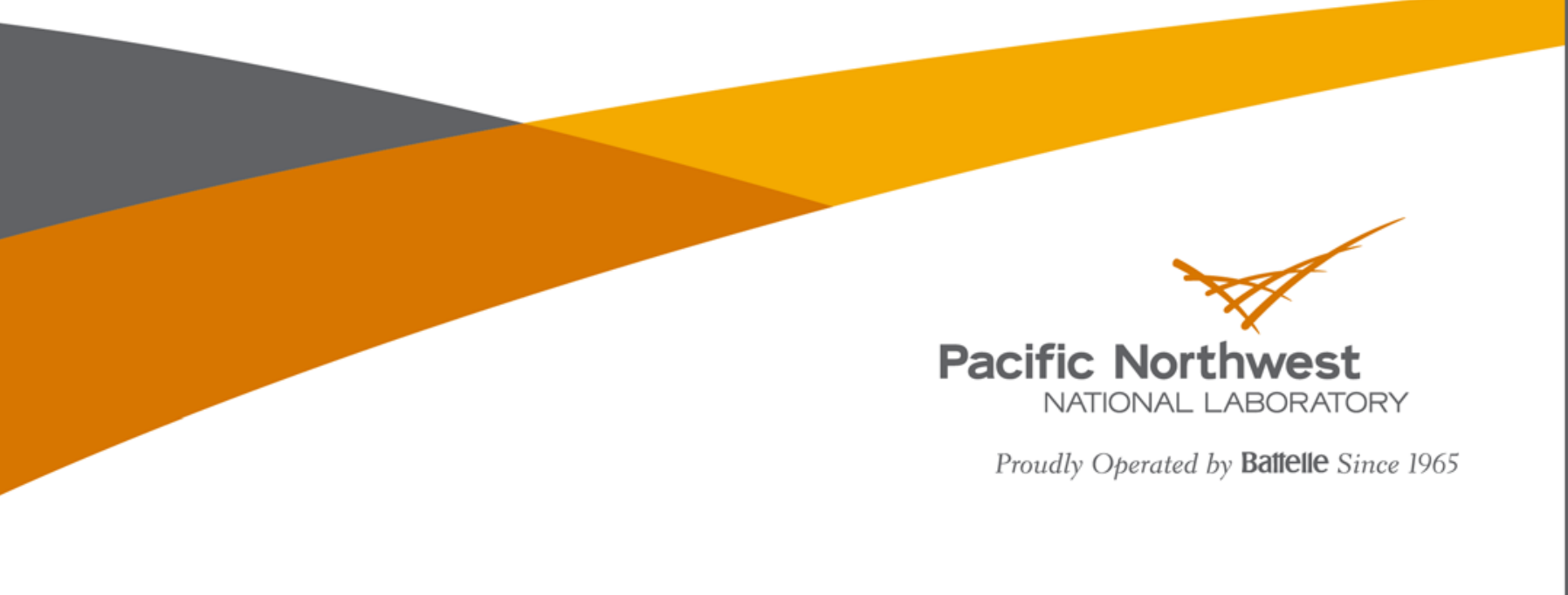




\title{
DISCLAIMER
}

This report was prepared as an account of work sponsored by an agency of the United States Government. Neither the United States Government nor any agency thereof, nor Battelle Memorial Institute, nor any of their employees, makes any warranty, express or implied, or assumes any legal liability or responsibility for the accuracy, completeness, or usefulness of any information, apparatus, product, or process diselosed, or represents that its use would not infringe privately owned rights. Reference herein to any specific commercial product, process, or service by trade name, trademark, manufacturer, or otherwise does not necessarily constitute or imply its endorsement, recommendation, or favoring by the United States Government or any agency thereof, or Battelle Memorial Institute. The views and opinions of authors expressed herein do not necessarily state or rellect those of the United States Government or any agency thereor.

\author{
PACIFIC NORTHWEST NATIONAL LABORATORY \\ operated by \\ BATTEI.I.T: \\ for the \\ UNITLD STAILS DLPARIMLNT OI LNERGY \\ under Contract DE-ACO5-76RLO1830 \\ Printed in the United States of America \\ Available to DOF and DOE contractors from the \\ Office of Scientific and Teclunical Infurmation, \\ P.O. Box 62, Oak Ridge, TN 37831-0062; \\ ph: (865) 576-8401 \\ fax: (865) 576-5728 \\ cmail: reports@ainonis.osti.gov \\ Available to the public from the National Technical Information Service, \\ U.S. Department of Commerce, 5285 Port Roy al Rd., Springfield, VA 22161 \\ ph: (800) 553-6847 \\ fax: $(703) 605-6900$ \\ email: ordersàntis.fedworld.gov \\ online ordering: http:/www.ntis.gov/ordering.htm
}




\section{Pacific Northwest National Laboratory Potential Impact Categories for Radiological Air Emissions Monitoring}

MY Ballinger

TL Gervais

JM Barnett

June 2012

Prepared for

the U.S. Department of Energy

under Contract DE-AC05-76RL01830

Pacific Northwest National Laboratory

Richland, Washington 99352 



\section{Contents}

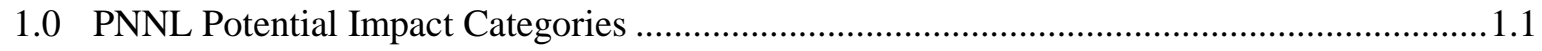

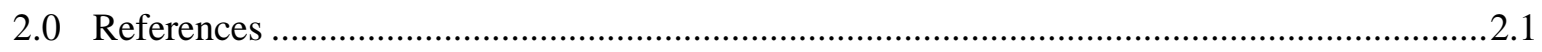

\section{Tables}

Table 1.1. ANSI/HPS N13.1-1999 Potential Impact Category Example Criteria ..........................1.1

Table 1.2. PNNL Potential Impact Categories............................................................................. 1.2

Table 1.3. PNNL Facilities Potential Impact Categories ............................................................

Table 1.4. Sampling System Requirements Based on PIC ........................................................ 1.5 



\subsection{PNNL Potential Impact Categories}

In 2002, the United States (U.S.) Environmental Protection Agency amended 40 Code of Federal Regulations (CFR) 61 Subpart H and 40 CFR 61 Appendix B Method 114 to include requirements from American National Standards Institute/Health Physics Society (ANSI/HPS) N13.1-1999 Sampling and Monitoring Releases of Airborne Radioactive Substances from the Stacks and Ducts of Nuclear Facilities for major emission points. Additionally, the Washington State Department of Health amended the Washington Administrative Code (WAC) 246-247 Radiation Protection-Air Emissions to include ANSI/HPS N13.1-1999 requirements for major and minor emission points when new permitting actions are approved. A result of the amended regulations is the requirement to prepare a written technical basis for the radiological air emission sampling and monitoring program. The technical basis must address the

- sampling objective

- graded approach for meeting the objectives

- relevant building operating conditions and airborne contaminants

- action levels that signal changing conditions of significance (section 4 of the standard).

A key component of the technical basis is the Potential Impact Category (PIC) assigned to an emission point. This paper discusses the PIC assignments for the Pacific Northwest National Laboratory (PNNL) integrated laboratory emission units. ANSI/HPS N13.1-1999 was reaffirmed in 2011 as ANSI/HPS N13.1-2011.

ANSI/HPS N13.1-1999 uses PICs to define a graded approach to sampling for airborne radioactive materials. The PICs used for illustrative purposes in the standard are based on potential "dose consequences that may occur assuming effluent attenuation or filtration devices present in the effluent stream have no effect" (ANSI/HPS N13.1-1999). This is comparable to the definition for Potential-ToEmit (PTE) used in radiological air emission regulations. The highest PIC suggested by the standard has potential consequences greater than 0.5 of an allowable limit. Table 1.1 illustrates the ANSI N13.1-1999 PIC ranges for an allowable limit of 10 millirem per year (mrem/yr).

Table 1.1. ANSI/HPS N13.1-1999 Potential Impact Category Example Criteria

\begin{tabular}{ccl} 
PIC & $\begin{array}{c}\text { Operating Range }- \\
\text { PTE (mrem/yr) }\end{array}$ & \multicolumn{1}{c}{ Monitoring and Sample Analysis } \\
\hline 1 & $>5$ & $\begin{array}{l}\text { Continuous sampling for a record of emissions and in-line, real-time monitoring with } \\
\text { alarm capability; consideration of separate accident monitoring system. }\end{array}$ \\
2 & $>0.1$ and $\leq 5$ & $\begin{array}{l}\text { Continuous sampling for record of emissions, with retrospective, offline periodic } \\
\text { analysis. }\end{array}$ \\
3 & $\leq 0.01$ and $\leq 0.1$ & $\begin{array}{l}\text { Periodic confirmatory sampling and offline analysis. } \\
\text { Annual administrative review of building uses to confirm absence of radioactive } \\
\text { materials in forms and quantities not conforming to prescribed specifications and } \\
\text { limits. }\end{array}$ \\
\hline
\end{tabular}


PNNL has adopted the suggested PIC definitions provided in ANSI/HPS N13.1-1999, as applied to the federal and state standards of $10 \mathrm{mrem} /$ year. ${ }^{1,2}$ Following the graded approach advocated in ANSI/HPS N13.1-1999, PNNL has defined an additional PIC category with PTE criteria orders of magnitude below that of PIC 4 to allow for appropriate and efficient permitting and management of radioactive materials with inconsequential contributions to potential offsite dose (Table 1.2). The PIC 5 category is employed to classify a site-wide use of materials that have either been released from radiological control according to the PNNL How Do I? (HDI) Work Control "Radiological - General" or have been determined to be Administratively Controlled Radioactive Materials or Non-dispersible Radioactive Materials according to RCP-3.1.01, Radiological Work Planning. ${ }^{3}$ When applicable, PNNL will permit PIC 5 items as a group for air emission purposes to allow for flexibility in the research and development environment by allowing site-wide use of these low-risk items. ${ }^{4}$ Site-wide PIC 5 utilization does not preclude the use of the materials in PIC 4 or higher permitted locations.

Table 1.2. PNNL Potential Impact Categories

\begin{tabular}{|c|c|c|}
\hline PIC & $\begin{array}{l}\text { Operating Range - } \\
\text { PTE (mrem/yr) }\end{array}$ & Monitoring and Sample Analysis \\
\hline 1 & $>5$ & $\begin{array}{l}\text { Continuous sampling for a record of emissions and in-line, real-time monitoring with } \\
\text { alarm capability; consideration of separate accident monitoring system. }\end{array}$ \\
\hline 2 & $>0.1$ and $\leq 5$ & $\begin{array}{l}\text { Continuous sampling for record of emissions, with retrospective, offline periodic } \\
\text { analysis. }\end{array}$ \\
\hline 3 & $>0.001$ and $\leq 0.1$ & Periodic confirmatory sampling and offline analysis. \\
\hline 4 & $>1 \mathrm{E}-6$ and $\leq 0.001$ & $\begin{array}{l}\text { Annual administrative review of building uses to confirm absence of radioactive } \\
\text { materials in forms and quantities not conforming to prescribed specifications and } \\
\text { limits. }\end{array}$ \\
\hline 5 & $\leq 1 \mathrm{E}-6$ & $\begin{array}{l}\text { Applied to a group of materials used site-wide. Administrative control through the } \\
\text { following steps: } 1 \text { ) The item is classified by Radiation Protection to be released from } \\
\text { radiological control (e.g., volumetrically released liquids }{ }^{5} \text { ) or is determined by } \\
\text { Radiation Protection to be Administratively Controlled Material or Non-dispersible } \\
\text { Radioactive Material; } 2 \text { ) Radiation Protection administers the classification programs } \\
\text { with input from the Effluent Management and Waste Operations Groups; and 3) } \\
\text { Radiation Protection maintains a record of these items and a periodic evaluation is } \\
\text { performed on the processes. }\end{array}$ \\
\hline
\end{tabular}

\footnotetext{
${ }^{1}$ Emissions of radionuclides to the ambient air from U.S. Department of Energy facilities shall not exceed those amounts that would cause any member of the public to receive in any year an effective dose equivalent of 10 mrem/yr. (40 CFR 61 Subpart H, 61.92)

${ }^{2}$ Emissions of radionuclides in the air shall not cause a maximum effective dose equivalent of more than $10 \mathrm{mrem} / \mathrm{yr}$ to the whole body to any member of the public. (WAC 173-480-040)

${ }^{3}$ Note that PIC 5 only applies to materials that were brought under radiological control and subsequently released; materials where radiological control was never required are not included in PTE calculations.

${ }^{4}$ The PNNL Start Clean Stay Clean Program may be considered in determining use locations for PIC 5 materials.

${ }^{5}$ The PTE calculated for $1 \mathrm{~L}$ of solution using volumetric release limits and worst case isotopes from each radionuclide group was less than 5E-9 mrem/yr. Therefore, hundreds of these items would not exceed a PTE of $1 \mathrm{E}-6$.
} 
Although PTEs for each emission unit are calculated annually using actual inventory, the PTE used for assigning PICs is the permitted PTE, which is based on maximum estimated inventory and throughput for permitted activities. For example, the 331 Building EP-331-01-V emission unit is permitted for a PTE $>0.1 \mathrm{mrem} /$ year and is considered a major emission unit. Therefore, this emission unit is considered PIC 2 instead of PIC 3 until it is downgraded to minor status. The PNNL-defined PIC categories are identified in Table 1.2.

PNNL has adopted the graded approach outlined in the standard and applied it to the PNNL PICs because the rigor of some of the requirements in the standard depend on the PIC category. Table 1.3 shows the PNNL emission units and identifies the PIC assigned to each based on the PNNL criteria in Table 1.2. Table 1.4 identifies the differences in sampling system requirements for the different PIC categories, as described in ANSI/HPS N13.1-1999.

New emission units and permitting actions will follow the guidance in Table 1.2. For existing emission units, a change to the PIC monitoring and sampling analysis requirements requires a permit modification and regulatory approval. For example, an emission unit going from a PIC 3 to a PIC 4 category will be considered for an "annual administrative review" in lieu of sampling during future permitting actions after regulatory approval (ANSI/HPS N13.1-1999). 
Table 1.3. PNNL Facilities Potential Impact Categories

\begin{tabular}{|c|c|c|c|c|c|}
\hline Building & Emission Unit(s) & $\begin{array}{c}\text { PTE } \\
\text { mrem/yr }\end{array}$ & $\begin{array}{l}\text { ANSI N13.1 } \\
\text { PIC }\end{array}$ & $\begin{array}{l}\text { PNNL } \\
\text { PIC }\end{array}$ & Comments \\
\hline 318 & EP-318-01-S & $1.7 \mathrm{E}-5$ & 4 & 4 & Sampled annually as required by permit. \\
\hline 325 & EP-325-01-S & $3.9 \mathrm{E}+2$ & 1 & 1 & Continuous sampling and monitoring. \\
\hline 331 & EP-331-01-V & 3.6 & 2 & 2 & Sampled continuously. \\
\hline 3410 & EP-3410-01-S & 3.7 & 2 & 2 & Sampled continuously. \\
\hline 3420 & EP-3420-01-S & 3.7 & 2 & 2 & Sampled continuously \\
\hline 3420 & EP-3420-02-S & $3.2 \mathrm{E}-4$ & 4 & 4 & $\begin{array}{l}\text { Radionuclide emissions determined using } 40 \text { CFR } 61 \text { Appendix D calculations in } \\
\text { lieu of monitoring. }\end{array}$ \\
\hline 3425 & Fugitive emissions & $2.8 \mathrm{E}-4$ & 4 & 4 & $\begin{array}{l}\text { Radionuclide emissions determined using } 40 \text { CFR } 61 \text { Appendix D calculations in } \\
\text { lieu of monitoring. }\end{array}$ \\
\hline 3430 & EP-3430-01-S & 4.2 & 2 & 2 & Sampled continuously. \\
\hline 3430 & EP-3430-02-S & $3.2 \mathrm{E}-4$ & 4 & 4 & $\begin{array}{l}\text { Radionuclide emissions determined using } 40 \text { CFR } 61 \text { Appendix D calculations in } \\
\text { lieu of monitoring. }\end{array}$ \\
\hline 3430 & $\begin{array}{l}\text { EP-3430-1606P-S } \\
\text { EP-3430-1608P-S } \\
\text { EP-3430-1610P-S } \\
\text { EP-3430-1612P-S } \\
\text { EP-3430-1614P-S }\end{array}$ & 7.4E-8 (еа) & 4 & 4 & $\begin{array}{l}\text { Perchloric acid hood emission units; PTE is per emission unit. Radionuclide } \\
\text { emissions determined using } 40 \text { CFR } 61 \text { Appendix D calculations in lieu of } \\
\text { monitoring. }\end{array}$ \\
\hline 361 & Fugitive emissions & $2.0 \mathrm{E}-4$ & 4 & 4 & $\begin{array}{l}\text { Radionuclide emissions determined using } 40 \text { CFR } 61 \text { Appendix D calculations in } \\
\text { lieu of monitoring. }\end{array}$ \\
\hline LSL II & $\begin{array}{l}\text { LSLII-01-V } \\
\text { LSLII-02-V }\end{array}$ & $\leq 5.0 \mathrm{E}-4$ & 4 & 4 & $\begin{array}{l}\text { Private Facility; PTE is sum of all emission units. Radionuclide emissions } \\
\text { determined using } 40 \text { CFR } 61 \text { Appendix D calculations in lieu of monitoring. }\end{array}$ \\
\hline RTL-520 & $\begin{array}{l}\text { RTL-10-V } \\
\text { RTL-11-V }\end{array}$ & $2.4 \mathrm{E}-2$ & 3 & 3 & Private Facility sampled quarterly; PTE is sum of all emission units. \\
\hline RTL-530 & Fugitive emissions & $\leq 5.0 \mathrm{E}-4$ & 4 & 4 & $\begin{array}{l}\text { Private Facility; PTE is sum of all emission units. Radionuclide emissions } \\
\text { determined based on smears and using } 40 \text { CFR } 61 \text { Appendix D calculations. }\end{array}$ \\
\hline
\end{tabular}


Table 1.4. Sampling System Requirements Based on PIC

\begin{tabular}{|c|c|c|c|c|c|}
\hline PIC & Sampling Site & Sample Nozzle & Stack Flow & Sample Flow & CAMS \\
\hline 1 & $\begin{array}{l}\text { Must meet acceptance } \\
\text { criteria for uniform } \\
\text { velocity, tracer gas, } \\
\text { and aerosol mixing \& } \\
\text { lack of cyclonic flow. }\end{array}$ & $\begin{array}{l}\text { Aerosol transmission ratio within range of } \\
0.8-1.3 \text { for } 10 \mu \mathrm{m} \text { (or greater) particles. } \\
\text { This depends on stack \& sample velocity, } \\
\text { so this ratio required over a range of } \\
\text { values if these vary. Aspiration ration of } \\
0.8-1.5 \text {. Aspiration ratio is related to } \\
\text { transmission ratio. }\end{array}$ & $\begin{array}{l}\text { Must } \\
\text { continuously } \\
\text { measure. }\end{array}$ & $\begin{array}{l}\text { Shall be varied in proportion to stack } \\
\text { flow in order to permit an accurate } \\
\text { assessment of the quantities of any } \\
\text { releases. A controller (continuous } \\
\text { control) shall be used to maintain the } \\
\text { ratio of the sample flow rate and } \\
\text { effluent flow rate within } \pm 20 \% \text { of a } \\
\text { predetermined value. }\end{array}$ & $\begin{array}{l}\text { Required, but may be } \\
\text { operated at a fixed } \\
\text { flow rate. However, } \\
\text { ratio of sample flow } \\
\text { to stack flow should } \\
\text { not vary by more } \\
\text { than } \pm 25 \% \text {. }\end{array}$ \\
\hline 2 & $\begin{array}{l}\text { Must meet acceptance } \\
\text { criteria for uniform } \\
\text { velocity, tracer gas, } \\
\text { and aerosol mixing \& } \\
\text { lack of cyclonic flow. }\end{array}$ & $\begin{array}{l}\text { For new or major modified emission units } \\
\text { (after } 9 / 2002 \text { ), aerosol transmission ratio } \\
\text { within range of } 0.8-1.3 \text { for } 10 \mu \mathrm{m} \text { (or } \\
\text { greater) particles. This depends on stack \& } \\
\text { sample velocity, so this ratio required over } \\
\text { a range of values if these vary. Aspiration } \\
\text { ration of } 0.8-.5 \text {. Aspiration ratio is related } \\
\text { to transmission ratio. }\end{array}$ & $\begin{array}{l}\text { Must } \\
\text { continuously } \\
\text { measure if } \\
\text { flow rate } \\
\text { varies by > } \\
20 \% \text { over } \\
\text { year. }\end{array}$ & $\begin{array}{l}\text { May be varied or may be held } \\
\text { constant. Continuous control if the } \\
\text { sample flow rate can vary by more } \\
\text { than } \pm 20 \% \text { over the sample period. }\end{array}$ & Not required. \\
\hline 3 & $\begin{array}{l}\text { Must meet acceptance } \\
\text { criteria for uniform } \\
\text { velocity, tracer gas, } \\
\text { and aerosol mixing \& } \\
\text { lack of cyclonic flow. }\end{array}$ & & $\begin{array}{l}\text { Only periodic } \\
\text { measurements } \\
\text { required. }\end{array}$ & $\begin{array}{l}\text { May be varied or may be held } \\
\text { constant. Continuous control if the } \\
\text { flow rate can vary by more than } \pm 20 \% \\
\text { over the sample period. }\end{array}$ & Not required. \\
\hline 4 & \multicolumn{5}{|c|}{$\begin{array}{l}\text { No requirements to sample or monitor per ANSI/HPS N13.1-1999, Table 2: “Annual administrative review of facility uses to confirm absence of } \\
\text { radioactive materials in forms and quantities not conforming to prescribed specifications and limits." }\end{array}$} \\
\hline 5 & \multicolumn{5}{|c|}{$\begin{array}{l}\text { As defined by PNNL, this category is a subgroup under PIC } 4 \text { allowing for a graded approach for managing radioactive materials with little to no } \\
\text { emission potential. Administrative control through the following steps: 1) The item is classified by Radiation Protection to be released from radiological } \\
\text { control or is determined by Radiation Protection to be Administratively Controlled Material or Non-dispersible Radioactive Material; 2) Radiation } \\
\text { Protection administers the classification programs with input from the Effluent Management and Waste Operations groups; 3) Radiation Protection } \\
\text { maintains a record of these items and a periodic evaluation is performed on the processes. }\end{array}$} \\
\hline
\end{tabular}





\subsection{References}

40 CFR 61, Appendix B, Method 114. 2002. "Test Methods for Measuring Radionuclide Emissions from Stationary Sources.” U.S. Code of Federal Regulations. U.S. Environmental Protection Agency, Washington, District of Columbia.

40 CFR 61, Appendix D. 2002. "Methods for Estimating Radionuclide Emissions.” U.S. Code of Federal Regulations. U.S. Environmental Protection Agency, Washington, District of Columbia.

40 CFR 61, Subpart H. 2002. "National Emission Standards for Emissions of Radionuclides Other Than Radon from Department of Energy Facilities.” U.S. Code of Federal Regulations. U.S. Environmental Protection Agency, Washington, District of Columbia.

ANSI/HPS - American National Standards Institute/Health Physics Society. 1999. Sampling and Monitoring Releases of Airborne Radioactive Substances from the Stacks and Ducts of Nuclear Facilities. ANSI/HPS N13.1-1999, Health Physics Society, McLean, Virginia. (Reaffirmed in 2011 as ANSI/HPS N13.1-2011)

PNNL - Pacific Northwest National Laboratory. 2011. Radiological Work Planning. RCP-3.1.01, Pacific Northwest National Laboratory, Richland, Washington.

PNNL - Pacific Northwest National Laboratory. 2012. Radiological - General. How Do I? Pacific Northwest National Laboratory, Richland, Washington.

WAC - Washington Administrative Code. 2007. “Ambient Air Quality Standards and Emission Limits for Radionuclides.” WAC 173-480, Olympia, Washington.

WAC - Washington Administrative Code. 2011. "Radiation Protection-Air Emissions.” WAC 246-247, Olympia, Washington. 



\section{Distribution}

\section{Local Distribution}

Pacific Northwest National Laboratory

J.M. Barnett

M.Y. Ballinger

C.J. Duchsherer

D.L. Edwards

T.L. Gervais

J.A. Glissmeyer

D.P. Higby

R.M. Pierson

M.J. Stephenson

R.D. Sharp

G.A. Stoetzel

C.J. Nichols

M.J. Pueschner

HTL
J2-25

BSRC

$\mathrm{J} 2-25$

K2-40

$\mathrm{J} 2-25$

K3-54

K8-32

$\mathrm{J} 2-40$

J2-25

J4-50

$\mathrm{J} 2-40$

J4-50

P7-08

P8-55

Pacific Northwest Site Office

T.L. Aldridge

K9-42

Washington Department of Health

P.J. Martell

B1-42 


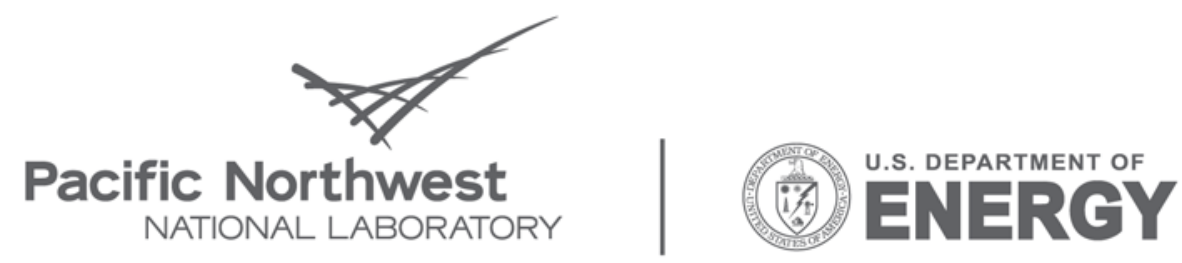

Proudly Operated by Battelle Since 1965

902 Battelle Boulevard

P.O. Box 999

Richland, WA 99352

1-888-375-PNNL (7665)

www.pnl.gov 